\title{
A Path of the Reformation of China's Stock Issuance Registration System
}

\author{
Hui Liu ${ }^{1}$ \\ ${ }^{1}$ School of Economics, Jinan University, Guangzhou, China \\ Correspondence: Hui Liu, School of Economics, Jinan University, Guangzhou 510632, China. Tel: \\ 86-132-4913-5225.
}

Received: March 27, 2017

Accepted: April 6, 2017

Online Published: April 7, 2017

doi:10.20849/abr.v2i1.141

URL: https://doi.org/10.20849/abr.v2i1.141

\begin{abstract}
Securities issuance audit system is the most basic system of a country's securities market, other systems play the role of ensuring its operation smoothly. The Third Plenary Session of the Eighteenth Central Committee of the Communist Party of China has established the registration system of stock issuance as the reform target. The registration system, that most mature markets used, can make up for the shortage of approval system of China's stock issuance audit system at present. However, the registration system also has a higher realization of the foundation. This paper analyzes the shortcomings of the stock issuance under the approval system, discusses the basis of the implementation of the registration system, and puts forward some suggestions for reference from the functions of the CSRC, the qualities of investors and the supporting system of stock issuance.
\end{abstract}

Keywords: securities issuance audit system, registration system, approval system

\section{Introduction}

The registration system refers to a system under sufficient information disclosure, which securities issuance applicant submits all information relating to the issuance in accordance with statutory requirements to the securities authorities for examination and apply for issuance. If the securities authorities have no objection within the statutory period, the application automatically enters into force. Mature markets such as the security market of the United States and Japan usually implement registration system.

There is a fundamental difference between the registration system and the approval system. Firstly, whether the securities authorities conduct a substantive audit. Under the registration system, the securities authority only conducts the formal examination of the authenticity, accuracy and completeness of the information submitted by the issuer, and does not review the profit status of the issuer, nor does it judge the value of the securities itself. In other words, a company, regardless of its size, profitability, and significance, can issue shares if only the company discloses the relevant information. Secondly, whether the right of issuance is granted by the securities authorities. The company obtains the right to issue when established under the registration system, while the right to issue is granted by the government under approval system after substantive review by securities authorities.

\section{Foundation of Registration System}

Most of the developed countries' securities market apply registration system, but not all markets can apply this system, which requires a higher realization of the foundation.

(1) the more mature market development

Multi-level capital market system is one of the important signs of mature market, in order to meet various financing needs, we must have a sound multi-level capital market system. In general, mature markets will develop different issuance and listing standards for different applicants, such as industry, size, profitability, etc., and provide diversified issuance and listing for applicants, such as incremental issuance and stock issuance, IPO and non-financing listing of listed companies. Only the market has developed to a certain extent can we open up the road for the registration system. 


\section{(2) high-quality market participants}

Securities market participants include issuers / listed applicants, intermediaries and investors. Under the registration system, the applicant, regardless of size, profit or not the company can apply for the listing, that is, the new shares for investors is no longer scarce resources, then the applicant needs to consider their own circumstances to avoid the failure of the issuance of the loss; for intermediaries, the underwriters, accountants and lawyers should apply their excellent professional knowledge of their duties, the underwriters should do a due diligence, carefully counseling enterprises, the accountants should strictly audit the financial situation of the enterprise, the lawyer should also issue a professional advice which must be in accordance with the requirements of the laws and regulations, because once the issue failed or the securities regulatory agencies found fraud, the underwriters, accountants and lawyers of integrity and credibility are adverse and shame. In the face of all kinds of financing, investors must have a wealth of investment knowledge and experience to identify high-quality stocks.

(3) smooth and convenient exit channels

Under the registration system, the listing access conditions are more relaxed, delisting as a listed company's exit channel, playing an important role in promoting the securities market to a virtuous circle. In the United States, for example, when a listed company fails to meet the criteria for a continuous listing, the listed company either applies for delisting or withdraws from the Securities and Exchange Commission (SEC). Different levels of trading platform have different delisting standards, such as the New York Stock Exchange as the main board market is more concerned about the company's performance, financial position and operating capacity, while transaction prices and trading volume is more concerned in the Nasdaq market, these different standards also constitutes a reference factor for listed companies to choose to market. After the delisting of listed companies, they can be transferred to the OTC market to continue trading, until the indicators to re-meet the listing standards, they can apply for listing again.

(4) perfect legal guarantee system

Under the registration system, the market which is the "invisible hand" allocate resources, the orderly operation of the market need to be lawful. On the one hand, information disclosure as the core of the registration system, we need to make it clear in the provisions of the law: disclose what content, how to disclose, what consequences if do not disclose; The characteristics of post control require that the law must clear the direction of supervision, maintain market order, such as administrative penalties, criminal offenses and civil liability and related treatment, while providing protection for investors to reduce investor risk, such as the US group litigation mechanism. Because of the large number of participants to solve the high cost of private litigation, which making investors willing to protect their rights through legal channels, which also to expand the public supervision of the team, so that listed companies dare not fake, otherwise they would pay a high price of fraud.

\section{Current Situation}

China's securities market has been established for nearly three decades, and the stock issuance system develops from the initial endorsement system to the approval system. With the development of market economy, drawbacks of approval system are gradually exposed.

(1) low securities issuance audit efficiency

Under the approval system, the CSRC has a high standard for substantive audit for the issuance of applicant. The applicant must prepare a large number of related materials under the guidance of the securities underwriters. Then, the CSRC reviews these materials one by one and convenes several rounds of meetings to resolve. Issuance examination committee appears to be weak when faces a large amount of application materials, so, the securities issuance audit efficiency is low. Generally, the applicants going for equity financing often have a specific investment projects. However, it is a long time from submission of materials to the final successful listing. The market opportunities are changing, and the project may have no investment value when getting the funds issued by the stock. In addition, low securities issuance audit efficiency leads to serious "barrier lake" phenomenon in securities market. There still have 725 enterprises waiting for IPO until November 17, 2016. In 2016, the CSRC has sped up the approval of IPO, and approved three batches of new shares issued approval that the cumulative number of new shares reached 38 in November, even at this rate, it still need a year and a half to audit the waiting enterprises. 


\section{(2) concentrated power of CSRC}

Under the approval system, the CSRC has the right to audit, that is to say, the issuer or listing applicants who want to obtain equity financing need to be approved by the CSRC, and if the qualification of applicant does not meet the issuance / listing standards, the CSRC has the right to refuse the application. This right is aimed to select high-quality stocks, reduce investors' risk and stay the securities market stable. However, it is a double-edged sword. First of all, excessive concentration of rights easily lead to corruption if there is no corresponding constraint mechanism. Secondly, some enterprises cook the books in order to meet the high audit standards, and whitewashing financial reports usually occurs. Thirdly, it is subjective to determine whether the stock worth to invest, which affected by their own knowledge and professional capacity. So a small number of people in CSRC make decisions for investors, itself is unreasonable. The last and most important, the concentrate power is to the disadvantage of effective allocation of resources. There exist all kinds of capital consumers who belong to different industries and have different scales in the market. However, various types of issuer selected by the same standard, and only the so-called "high-quality enterprises" allowed to enter into the market, and enterprise that is small, has no profit now and stays in start-up period is denied to list. Various resources which can't fully access to the market will really have an impact on the relation of supply and demand, and then affect resources to allocate optimally.

(3) poor-quality market participants

Investors are important participants in the securities market. High-quality investors are conducive to maintaining markets' stability. Generally speaking, institutional investors are more rational, have more profound professional knowledge, richer investment experience, more available funds, and more tolerance for risk. In mature markets, the vast majority of investors are institutional investors. On the contrary, it is the opposite situation in China's securities market. According to the monthly report of China Securities Depository and Clearing Co., Ltd., the number of investors at the end of the period was 118,110,400 until the end of December 2016, of which $117,784,200$ were individual investor, accounting for $99.72 \%$, and 326,200 were institutional investor, accounting for only $0.28 \%$. So China's securities market is dominated by individual investor. Under approval system, issuance appliances need to pass audits, which is considered to be a powerful endorsement for the risk of investment. And then investors will not do some independent research about the value of stock. Phenomenon that investors jump on the bandwagon always occur in the market. On the one hand, investors suffered heavy losses from the share prices fall. On the other hand, it is common that new issued shares frequently reach more than a dozen, or even dozens of trading boards. Investors simply do not care about the value of the stocks, but purchase stock when issue a new stock. This type of audit is not conducive to cultivating investors' rational investment behavior and healthy investment psychology.

(4) unperfect supporting system

Effective legal system can make the whole process of the issuance of securities have laws to prosecute, and the interests of all parties involved in the stock market can be guaranteed. Though it is regulated about information disclosure, continuing listing, delistings and supervision at present, the realities are unsatisfactory. In terms of information disclosure, documents required for issuance and listing are not completely public. For example, issuance applicant pre-disclose prospectus, but the CSRC's audit opinion is not open to the public, and the public can not view some of the reference documents, so investors can not fully know the relevant information about issuance applicant all the time, and the scope of publics' supervision is also limited, which is not conducive to protecting the interests of public investors. In addition, what has been disclosed is not entirely true, some appliances cook the books in order to meet the audit standards, thus credibility of disclosed information greatly reduced. The information disclosure system is the fundamental basis of the securities markets, thus misrepresentation is deemed to be issuer's serious violation of information disclosure obligation. In terms of the delisting system, though delisting rules are written into relevant laws, there barely has listed companies delisted in China's securities market, even these companies are in bad management, bad profit, and not reaching listing qualification, they make every endeavor to keep shell resources. In terms of supervision, the CSRC play both "goalkeeper" and "referee" role, the power of the CSRC is distracted by supervision-and-audit-in-one situation, so that the CSRC unable to focus all the attention on one thing. The supervision and punishment mechanism is still evolving, which administrative penalties and criminal penalties are always the primary punishment for illegal behaviors at present, cost of the crime is so low that false issuance frequently exist in market. 


\section{Conclusions and Suggestions}

The system of issue shares change from the approval system to the registration system is not overnight, only when China's economic and securities market develop to a certain advanced level, can registration system put into effect. So, our country should also be improved from the following aspects.

\subsection{Adjust the CSRC's Function}

We can see the CSRC's function is "to maintain the market open, fair and just, to protect legitimate rights and interests of investors, especially smaller investors, to promote the healthy development of capital markets" when we click into the CSRC's official website, but the decisions whether an enterprise can issue stock are left to the CSRC under the approval system, and the same standard, that is subjective, is used to judge the applicants in different industries and scales. It is difficult to say that these actions maintain the fairness of the market. To select high-quality enterprises and make decisions for investors, these actions not always protect the interests of investors. In addition, excessive administrative intervention lead to inefficient audit and supervision, which is not favorable to healthy development of the securities market. The CSRC, even if we only understand it from its literal meaning, it means to supervise the behavior of listed companies and manage the operation of the market. So the CSRC should focus its work on supervision and protect the interests of public investors to the greatest extent.

Firstly, to segregate the right of supervision and audit. Now the CSRC has the right both to audit shares waiting to issue and supervise behavior of listed companies, the CSRC's energy is dispersed by too much responsibility. Substantive audit contains many complicated process, which takes time and energy but may not reach the desired purpose. Some of the listed enterprises suffer from achievements decline, the audit effect is widely criticized by investors, so the CSRC should entirely separate the right of issuance audit from its power or maintain the right of regulation compliance about information disclosure. That is to say, the CSRC gradually weaken the audit of applicant's continued profitability, but to review the authenticity, accuracy, integrity and timeliness of information disclosure according to the registration system, leave the work of value judgement to investors, reduce the workload and improve the efficiency of the audit, thus the CSRC can focus on supervision after audit, and companies will strive to improve their own competitiveness to issue successfully. It can be described as multiple purposes.

Secondly, to separate the audit right of issuance and listing. Article 48 of China's "Securities Act" provides that: To apply for transactions in listed securities shall be filed to the stock exchange, the stock exchange audit the qualification of appliances, and then sign a listing agreement by the two sides. However, the actual situation of China's stock market is that the stock exchange is useless. Approved applicants are, without exception, listed in the stock exchange, which is not conducive to the construction of multi-level capital market system. The CSRC should learn the practice of mature markets that the audit right of listing leave back to the stock exchange, thus the advantages are reflected as follows. At first, there is competition between the stock exchanges that have no administrative identity, so, in order to attract more enterprises to list, on the one hand, the stock exchanges will strive to improve the audit methods and efficiency to shorten the financing process for enterprises and provide enterprises with a convenient listing experience, on the other hand, the stock exchange will carefully select high-quality listing applicants to improve the quality of itself, provide a high-quality trading environment to applicants and investors, create a virtuous circle and promote the prosperity of the securities market. Secondly, it is the demand of construction of multi-level capital market that audit right of listing leave to the stock exchange. The applicant may choose to apply for listing on the stock exchange after audit, or not to list, which promote the development of OTC market. Finally, the situation of abusing power will be curb effectively if audit right of listing leave to the stock exchange. The stock exchange must public the audit process in order to attract more companies to list, then prevent corruption effectively.

\subsection{Improve the Quality of Investors}

To promote the development of the market, we must improve the weak links in the market. In China's securities market, individual investors are dominant, who have small size of money, uneven securities investment level and poor risk tolerance, so, they are vulnerable groups in market. If the registration system carried in China, the number of listed companies will increase, thus investors need to analyze the company's investment value based on public information, and make decisions that whether to buy the stock, how many stocks and which price to purchase, which requires investors to have the ability to judge and decide rational. Therefore, improve the quality of investors is an important part during the transition from the approval system to the registration system. 
First of all, the CSRC should strengthen the education of investors about the investment knowledge, improve their information analysis ability and rational decision-making ability. Secondly, to develop institutional investors and encourage they enter the market. with their professional knowledge system, large scale of funds and strong risk tolerance to maintain the stability of the market. Finally, to develop multi-level capital market system, so that investors can accumulate investment experience in multiple markets.

\subsection{Improve the Supporting System}

The supporting system of stock issuance is a series of systems that protect the normal operation and maintain the order of the securities market. When all kinds of possible cases are written into the law and give them legal effect, the right will be put into the cage of the system and prevent corruption efficiently, then all kinds of rights of investors will be able to realize orderly.

(1) improve the information disclosure system

Information disclosure system is the core of the registration system, but its current situation is very awkward due to the audit of the CSRC under the approval system. Although information disclosure is regulated in the Securities Act, the CSRC's substantive audit weaken the function of information disclosure, the applicant and intermediary agencies are focused on how to pass the CSRC's audit, and they argue that it is not really important whether the disclosed information is true as long as they passed the audit. So, inaccurate information usually occur in order to achieve the audit standards. The CSRC had to improve the information disclosure system to change this situation.

First of all, the CSRC should further regulate the standards and content of information disclosure. Disclosed information, which should be true, accurate, complete and timely reflect the business situation, is an important channel for investors to study the enterprises. So, the CSRC's audit opinion on the applicants also should feedback to investors synchronously. Secondly, to improve the way that information disclose. The majority investors of China's stock market is individuals, who are the receptors of information, the information should be so easy as possible that investors can understand and maximize the function of information. Thirdly, to reduce the cost of access to information. Now, people can obtain a lot of information anytime and anywhere with developed network, the securities market can also make use of this advantage to simplify the way to obtain information, which investors can get any information through fingertips anytime. Finally, the CSRC should act vigorously against false information disclosure and increase the illegal costs, so that the issuer did not dare to cheat investors

(2) establish a sound delisting mechanism

November 2014 the CSRC issued "opinions on the reformation and implementation of the delisting system ", the "opinions" made explanations in the voluntary delisting, compulsory delisting and delisting indicators, which means the delisting system of China's securities market go one step further. However, the phenomenon of " barrier lake " in the securities market is still serious, and the shell resources are still scarce. Companies do not take the initiative to withdraw from the market even if they manager badly, and they can take the opportunity with the shell resources through asset-restructuring. It is regulated in "Securities Law " that the listed stocks shall be suspended for three consecutive years of losses, and if the fourth year loss continue, the listed stocks shall be terminated. The listed companies take advantages of the law and do it on purpose--to turn around temporarily to achieve the purpose of not delisting. In 2016, in order to manager the disarray, the CSRC takes action to the hype of shell resource frequently. But this is not enough, the CSRC should increase the intensity of law enforcement, and urge the "Securities Law" to complete the revision, establish a sound delisting system, and implement strictly according to the delisting standard. To improve the multi-level capital market system, and it is also a delisting channel that listed companies can "transfer board" flexible between many markets. The survival of the fittest mechanism is conducive no only to cultivating risk awareness of listed companies, promoting the efficient management of listed companies, but also to guaranteeing benign ecological circulation of the securities market.

(3) improve the investor protection mechanism

The core purpose of legislation of the securities market is to maintain the order of the market, ensure its normal operation, and maximize protection of the legitimate rights and interests of investors. Investors as the recipient of the information are naturally in a weak position because of the information asymmetry. Therefore, regulators should act vigorously against behaviors that damage the interests of investors, such as insider trading, false statements and rigging the market, to create a fair and legitimate trading environment. 
On the one hand, the CSRC should persist in scientific legislation. To improve the investor protection mechanism in the "Securities Law", so that the interests of investors have a legal basis. At present, the main punishment mechanism in China's securities market is administrative punishment, which has the features of low illegal cost and weak deterrence force. So, they should reify the dominance of the civil liability and criminal responsibility in the punishment mechanism. For instance, to set the terms of investor protection, and establish responsibility assigning mechanism. If the enterprise applies for listing, it should provide property guarantee by legal representative, the controlling shareholder and the company manager, and they shall undertake joint liability once the company does fraud. Or the CSRC can follow the example of class-action lawsuit mechanism of the United States. The number of victims of fraud is often large, other victims of investors are still living in accordance with their own life without being disturbed after selecting a chief plaintiff. When recovered, the compensation automatically transferred to victims' bank card and they do not need to rush to litigation, which greatly reduce the cost of litigation and investors will be happy to engage such a lawsuit, which virtually increased the power of public supervision. On the other hand, the CSRC should strengthen the law enforcement. The quality of legal protection depends on the implementation. They should stay zero tolerance against infringement of the interests of investors, resolutely fight all forms of illegal acts, and increase the cost of illegal, so that listed companies don't want to or dare to do fraud.

\section{References}

Fan, Y., Laws, S. O., \& University, C. S. (2016). A Study of Implementation Paths to China's New Stock Issue and Registration System. Journal of Neijiang Normal University.

Li, S. (2015). Discussion on Several Major Issues in the Reform of Registration System of IPO. Tribune of Political Science \& Law.

Lianshu, G. U., Wang, H., \& Wang, H. (2012). A Path to Transform China's Share Issue Audit System from Approval System to Registration System. Journal of Central University of Finance \& Economics, (11), 0-0.

Shen, Z. (2011). A Popular Misconception: Registration System and Approval System. Securities Market Herald.

Yang, C. (2015). Approval System to Registration System of Stock Issuance in China's Capital Market---To Perfect the Stock Issue System in China. Reformation \& Strategy.

Yong, M. A. (2015). Thoughts of Stock Issuance Registration System Reform. Journal of Changchun Finance College.

\section{Copyrights}

Copyright for this article is retained by the author(s), with first publication rights granted to the journal.

This is an open-access article distributed under the terms and conditions of the Creative Commons Attribution license (http://creativecommons.org/licenses/by/4.0/). 